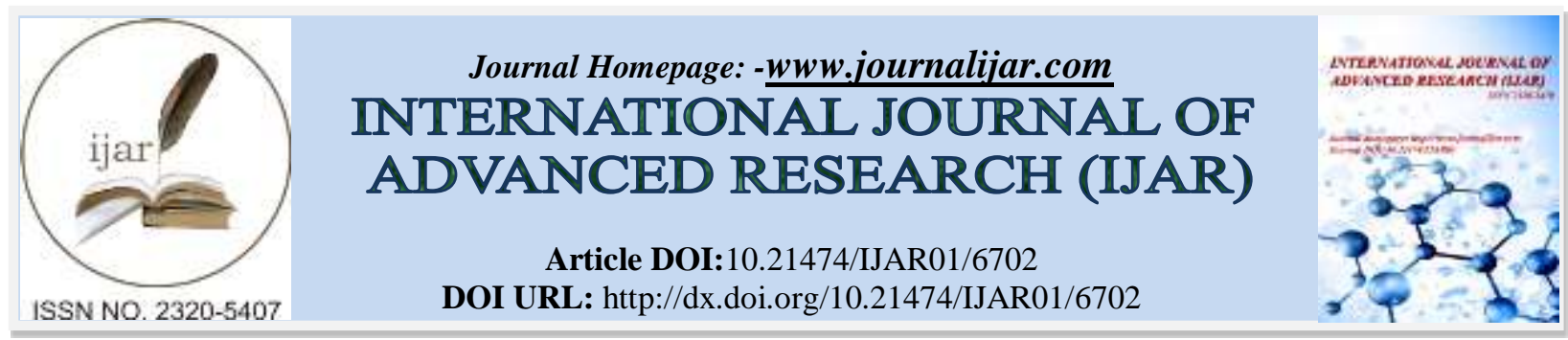

RESEARCH ARTICLE

\title{
TECHNOLOGICAL PARAMETERS OF SUGARCANE VARIETIES ATTACKED BY DIATRAEA SACCHARALIS.
}

\author{
Wagner José Machado da Silva ${ }^{1}$, Flávia Aparecida Santos Matias Machado da Silva ${ }^{1}$, Renê Michel Ribeiro \\ Pereira $^{1}$, Guilherme Castanheiro de Souza ${ }^{1}$, Hiago Augusto Amaral Sacco', Camila Regina Silva Baleroni \\ Recco $^{2}$, Jeruska Azevedo Moreira Brenha ${ }^{2}$ and Lucas Aparecido Manzani Lisboa ${ }^{2}$. \\ 1. Undergrade student, in Agronomy, at Educational Foundation of Andradina, state of São Paulo, Brazil. \\ 2. Lecture, in Agronomy, at Educational Foundation of Andradina, state of São Paulo, Brazil.
}

\section{Manuscript Info}

Manuscript History

Received: 09 January 2018

Final Accepted: 11 February 2018

Published: March 2018

Keywords:-

Saccharum officinarum, Fiber, Brix, Purity.

\begin{abstract}
An alternative to the control of sugarcane borer is the choice of the more resistant varieties that adapt themselves to different production systems, guarantying a better productivity. This work aimed to evaluate technological parameters of sugarcane varieties attacked by Diatraea saccharalis. The experiment was implemented in a randomized $2 \times 9$ factorial scheme, from 2 different cultivation cycles, 2016 and 2017, with 9 varieties of sugarcane: CTC-9001; CT04-6043; CTC-7; CTC22; CTC-25; CTC-9003; RB97-5952; RB96-6928 e RB85-5453, with 4 repetitions, 36 plots in total. At the end each cultivation cycle (2016 and 2017), it was evaluated the following parameters: tons of sugarcane's stem per hectare (TSH); percents of attacked stems (\%AS); Pol percents in broth (\%Pol); percents of sugarcane's fiber (\%Fiber); percents of purity in broth (\% Purity); Brix value of broth ( ${ }^{\circ}$ Brix); and total-recoverable sugar per ton of sugarcane (TRS). The varieties CT046043 and CTC7 had lower values of fiber and higher incidence of borer. The presence of sugar cane drill reduced the quality and quantity of sugarcane stalks. The variation of $10 \%$ in fiber content in sugarcane caused a $71 \%$ difference in the incidence of Diatraea saccharalis.
\end{abstract}

Copy Right, IJAR, 2018,. All rights reserved.

\section{Introduction:-}

The demand of new sources of renewable energy sets sugarcane culture as an alternative to electric power and fuel (Lima et al., 2008), which leads to greater budgets in sugarcane sector in order to search varieties with better productive responses. According to Costa et. Al. (2011) a few works relate interactions between planting environments and cultivation cycles, being necessary the knowledge of the responses of the genetic interferences to the culture's environmental factors.

Aude (1993) reports that sugarcane produces more dry mass per planting area than others forages, the author also states that a marked tillering occurs in the early stages that may result in a higher number of stem able to industry at the final harvest (Souza et al., 2016; SINGH et al., 2016). During the cultivation cycles, the plant is susceptible to plagues' attack; one of them is the sugarcane borer (Diatraea saccharalis Fabr. (Lepidoptera: Crambidae)). This negatively influences in the productive process, thus causes damages in the raw material at the end of the process. 
Borer's attack affects on the quality of the technological parameters of the sugarcane, mainly on its brix value, which measures the total reactive sugar and tons of sugarcane per hectare (Dinardo-Miranda, 2008).

An alternative to the control of sugarcane borer is the choice of more resistant varieties (Medeiros et al., 2016) or that have a higher fiber content in the stems making a physical barrier to the sugarcane borer. Elevation in fiber content is acceptable till the limit between 10,5 to 12,5\% (Rodolfo Junior et al., 2016), since a greater value turns into a limitation factor in the milling process (Souza et al. 2005). Alongside the borer's attack, biotic stresses and biotic can influence the technological parameters of sugarcane (Showler, 2016); such as chemical soil attributes (Zambrosi et al., 2017) and even the choice of the harvest method.

That way, this work aimed to evaluate technological parameters of sugarcane varieties attacked by Diatraea saccharalis.

\section{Materials and methods:-}

Installing the experiment:-

The experiment was installed on August, 2015, at Usina Ipê, in Nova Independência, São Paulo State, Brazil; geographic coordinates $21^{\circ} 9^{\prime} 58.739$ "S and 51 ${ }^{\circ} 28^{\prime} 1.660^{\prime \prime} \mathrm{W}$; with altitude of $337 \mathrm{~m}$. According to Koeppen the region's climate is classified as Aw with rainy summers and dry winters.

The experimental area was implemented in a $2 \%$ slope soil relief, in a soil classified as Argissolo Vermelho-amarelo férrico (Embrapa, 2013), displaying the following chemical attributes: $4.8 \mathrm{pH}(\mathrm{CaCl}) ; 11.0 \mathrm{~g}$ of Organic Matter $\mathrm{dm}-3 ; 9.0 \mathrm{mg}$ of $\mathrm{Pdm}^{-3}$ (resin); $1.3 \mathrm{mmol}$ of $\mathrm{K} \mathrm{dm}^{-3}$ (resin); $13.9 \mathrm{mmol}$ of Ca dm${ }^{-3}$ (resin); $5.94 \mathrm{mmol} \mathrm{of} \mathrm{Mg} \mathrm{dm}^{-3}$

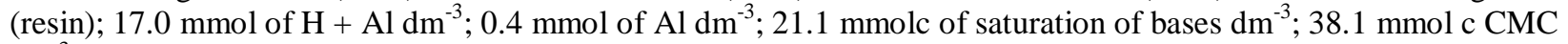
$\mathrm{dm}^{-3} ; 55.4$ Saturation per base (V\%); 1.9 Saturation per Al (m\%), and was fertilized according to Raij et al. (1996).

The experiment was implemented in a randomized 2x9-factorial scheme, from 2 different cultivation cycles, 2016 and 2017, with 9 varieties of sugarcane: : CTC-9001; CT04-6043; CTC-7; CTC-22; CTC-25; CTC-9003; RB975952; RB96-6928 e RB85-5453, with 4 repetitions, 36 plots in total. Each plots was made of 4 lines with 20 m length and $1.5 \mathrm{~m}$ spacing, $120 \mathrm{~m}$ in total. Eighteen viable gems were planted, by using mechanization, per linear meter of groove; $0.5 \mathrm{~L} \mathrm{ha}^{-1}$ of piraclostrobin and $0.1 \mathrm{~L} \mathrm{ha}^{-1}$ of Bacillus subtilis and Bacillus licheniformis were applied on gems.

During the conduction of the experiment, all the cultivars treatments were carried out when it was necessary. Figure 1 shows the average values of rain while the experiment was conducted.

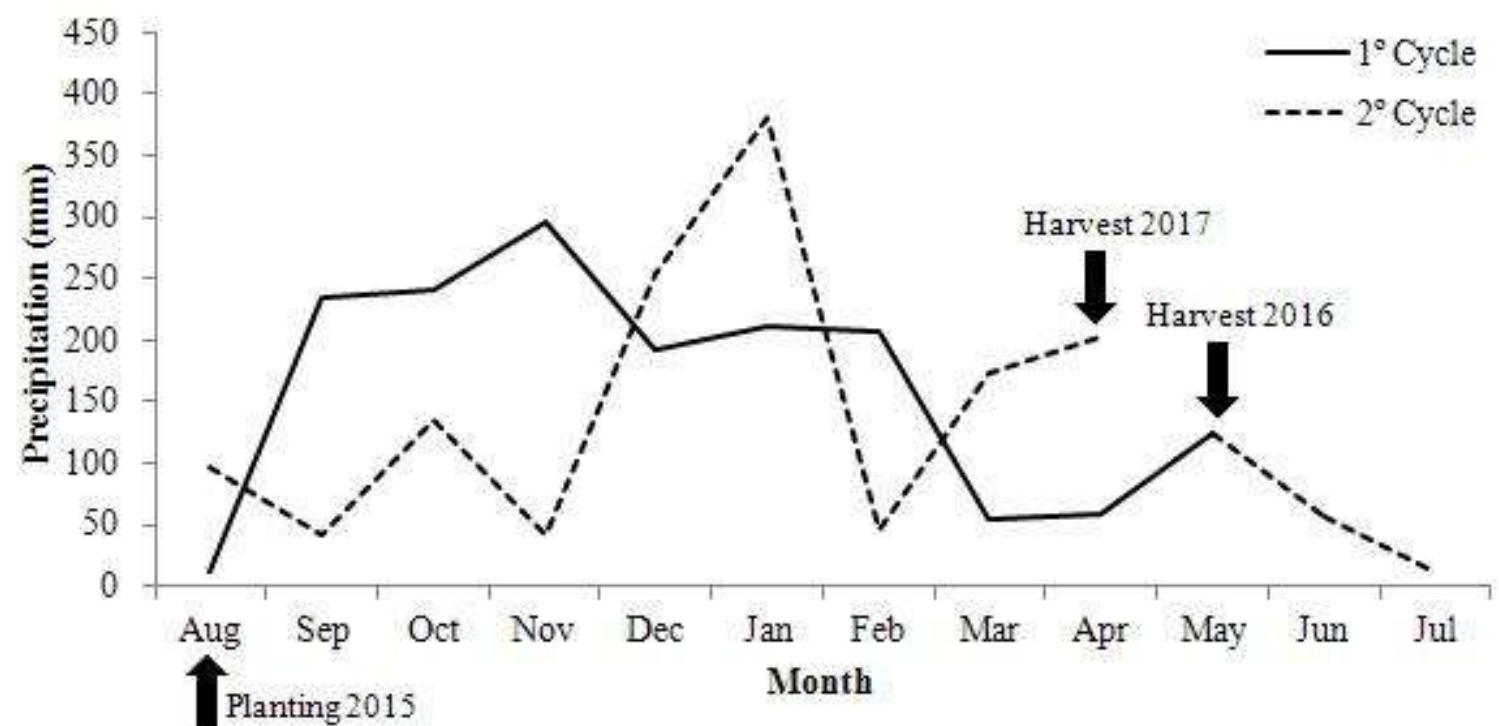

Figure 1:- The average values of rain while the experiment was conducted. 


\section{Evaluation of parameters:-}

The harvest were done on May, 2016 and April, 2017 by using mechanization in total plots, in which the values were converted in tons of sugarcane's stem per hectare (TSH). Also, twenty-five longitudinally cut stems were randomly selected to determine of percents of attacked stems (\% AS).

The following parameters were evaluated as well: Pol percents in broth (\% Pol); percents of sugarcane's fiber (\%Fiber); percents of purity in broth (\%Purity); Brix value of broth ( ${ }^{\circ}$ Brix); and total-recoverable sugar per ton of sugarcane (TRS) (Consecana, 2006).

\section{Statistical analysis:-}

The data were submitted to analysis of variance by the $\mathrm{F}$ test $(\mathrm{p}<0.05)$ and their averages were compared by the Scott-Knott test at 5\% probability (Banzatto and Kronka, 2013). The statistical program Assistat 7.7 (Silva and Azevedo, 2016) was used.

\section{Results and discussion:-}

On the parameter Pol percents in broth, it was not observed an interaction between the factors, as Chart 1 shows. Varieties CT046043; CTC25; CTC9003 and RB855453 showed lower average values as compared to the others, with a $14,92 \%$-difference between them, being an important data in the choice of varieties.

Chart 1:- Average values of Pol percents in broth (\%Pol); percents of sugarcane's fiber (\%Fiber); percents of purity in broth (\% Purity) and Brix value of broth ( ${ }^{\circ}$ Brix) of sugarcane attacked by borer.

\begin{tabular}{|c|c|c|c|c|}
\hline & Pol (broth) & $\%$ Fiber (broth) & \%Purity (broth) & ${ }^{\circ}$ Brix (broth) \\
\hline \multicolumn{5}{|c|}{ Varieties (V) } \\
\hline CTC9001 & $13,52 \mathrm{a}$ & $12,04 \mathrm{a}$ & $81,41 b$ & $17,78 \mathrm{a}$ \\
\hline CT046043 & $12,89 \mathrm{~b}$ & $11,67 \mathrm{a}$ & $81,69 b$ & $16,79 b$ \\
\hline CTC7 & $13,38 \mathrm{a}$ & $11,56 \mathrm{a}$ & $82,07 \mathrm{~b}$ & $17,36 \mathrm{a}$ \\
\hline CTC22 & $13,39 a$ & $12,13 \mathrm{a}$ & $83,31 \mathrm{a}$ & $17,25 \mathrm{a}$ \\
\hline CTC25 & $12,50 \mathrm{~b}$ & $11,70 \mathrm{a}$ & $81,08 \mathrm{~b}$ & $16,44 b$ \\
\hline CTC9003 & $12,61 b$ & $12,06 \mathrm{a}$ & $82,14 b$ & $16,26 b$ \\
\hline RB975952 & $14,34 \mathrm{a}$ & $12,40 \mathrm{a}$ & $85,24 a$ & $17,98 \mathrm{a}$ \\
\hline RB966928 & $13,71 \mathrm{a}$ & $12,17 \mathrm{a}$ & $83,04 a$ & $17,49 a$ \\
\hline RB855453 & $12,20 \mathrm{~b}$ & $11,95 \mathrm{a}$ & $79,74 b$ & $16,11 b$ \\
\hline $\mathrm{F}(\mathrm{V})$ & $4,3643 * *$ & $1,6421 \mathrm{~ns}$ & $4,5268 * *$ & $5,4490 * *$ \\
\hline \multicolumn{5}{|l|}{ Year (year) } \\
\hline 2016 & $15,81 \mathrm{a}$ & $12,35 \mathrm{a}$ & $85,81 \mathrm{a}$ & $18,41 \mathrm{a}$ \\
\hline 2017 & $10,53 b$ & $11,57 b$ & $78,57 b$ & $15,69 b$ \\
\hline $\mathrm{F}(\mathrm{Y})$ & $599,1681 * *$ & $29,6543 * *$ & $220,0146 * *$ & $197,2045^{* *}$ \\
\hline $\mathrm{CV} \%$ & 6,94 & 5,04 & 2,52 & 4,82 \\
\hline GA & 13,17 & 11,96 & 82,19 & 17,05 \\
\hline VxY & $1,7628 \mathrm{~ns}$ & $2,2523^{*}$ & $2,2270^{*}$ & $1,8038 \mathrm{~ns}$ \\
\hline
\end{tabular}

MSD: Minimum Significant Difference; CV: coefficient of variation; MG: General Average and F: value of F, calculated from the factors; V: variety; Y: year; **significant at $1 \%$ level of probability $(\mathrm{p}<0.01)$; * significant at $5 \%$ level of probability $(p<0.01)(0,01=<p<0.05)$; ns - non-significant $(p>=0.05)$. Averages on columns followed by the same letter do not differ ecstatically. It was used Scott-Knott test at $5 \%$ probability.

As the cultivation cycle factor is considered, the first year of cultivation presented a higher average value, being this difference of $33.39 \%$ when compared to the second cycle. This result can be explained by the fact that the plant presents greater vigor, which allows a greater accumulation of sucrose in its stems. The variation of Pol can affect the sugar's quality and even alcohol's, Ekpélikpézé et al. (2016) stated that this variation is an important factor to choose the best variety, since they easily adapted to different production systems, their genetic potential is expressed (Tyagi and Naidu, 2016).

Due to the capacity of adaptation of sugarcane varieties to the ambient, their anatomic ultrastructures can be potentialized, mainly on quality and amount of lignin in the fibers, which is an important characteristic on resistance 
to plagues'attack, even on the break of stems (Daniel et al. 2016). An interaction between the parameter percents of sugarcane's fiber (\%Fiber) was observed, as Chart 1 shows.

At the first cultivation cycle, varieties CT046043 and CTC7 displayed lower values on percents of sugarcane's fiber (\%Fiber), with a 10\%-difference from the varieties that showed a higher value. However this variation was not observed at the second cultivation cycle. CT046043 and CTC7 are new varieties available on the sugarcane energy sector, it is recommended their use with low wind incidence, which can lead to the fall of its stems, as Chart 2 shows.

Chart 2:- Average Values of \%Fiber (broth) of sugarcane varieties of sugarcane attacked by borer.

\begin{tabular}{|l|c|c|}
\hline & 2016 & 2017 \\
\hline CTC9001 & $12,46 \mathrm{aA}$ & $11,62 \mathrm{aA}$ \\
\hline CT046043 & $11,78 \mathrm{bA}$ & $11,55 \mathrm{aA}$ \\
\hline CTC7 & $12,02 \mathrm{bA}$ & $11,09 \mathrm{aB}$ \\
\hline CTC22 & $12,30 \mathrm{aA}$ & $11,96 \mathrm{aA}$ \\
\hline CTC25 & $11,66 \mathrm{aA}$ & $11,74 \mathrm{aA}$ \\
\hline CTC9003 & $13,09 \mathrm{aA}$ & $11,03 \mathrm{aB}$ \\
\hline RB975952 & $12,71 \mathrm{aA}$ & $12,09 \mathrm{aA}$ \\
\hline RB966928 & $12,49 \mathrm{aA}$ & $11,84 \mathrm{aA}$ \\
\hline RB855453 & $12,63 \mathrm{aA}$ & $11,27 \mathrm{aB}$ \\
\hline Aver & \\
\hline
\end{tabular}

Averages followed by the same letter do not ecstatically differ between them. It was used Scott-Knott test at 5\% probability. Collum: Captal letters; Rows: Small letters.

The fiber content of less than $10.5 \%$ is an undesirable factor for the sugar and alcohol industry, as the boilers use sugarcane bagasse originated in milling of stems to generate steam, being recommended as ideal a fiber content between 10,5 and 12,5\% (RODOLFO JUNIOR et al., 2016). That way, despite varieties CT046043 and CTC7 have show lower values as compared to other varieties, their fiber content is suitable.

According to Souza et al. (2005), a higher fiber content in stem can be considered an uneconomic factor to industry, thus mills are set to grind sugarcane with nearly $12,5 \%$ fiber content., in case of an addition o between 0,5 and $1,0 \%$, the milling process would be impaired, which could lead to $1,85 \mathrm{Kg}$ of sugar per ton of grinded sugarcane.

It was observed a interaction between factors, as Chart 1 shows to the variable Purity\%. Chart 3 shows average Values of \%Purity (broth) of sugarcane varieties of sugarcane attacked by borer.

Chart 3:- Average Values of \%Purity (broth) of sugarcane varieties of sugarcane attacked by borer.

\begin{tabular}{|l|c|c|}
\hline & 2016 & 2017 \\
\hline CTC9001 & $83,65 \mathrm{bA}$ & $79,17 \mathrm{bB}$ \\
\hline CT046043 & $85,06 \mathrm{bA}$ & $78,33 \mathrm{bB}$ \\
\hline CTC7 & $85,20 \mathrm{bA}$ & $78,95 \mathrm{bB}$ \\
\hline CTC22 & $85,50 \mathrm{bA}$ & $81,12 \mathrm{aB}$ \\
\hline CTC25 & $85,29 \mathrm{bA}$ & $76,87 \mathrm{bB}$ \\
\hline CTC9003 & $86,08 \mathrm{bA}$ & $78,20 \mathrm{bB}$ \\
\hline RB975952 & $88,48 \mathrm{aA}$ & $82,00 \mathrm{aB}$ \\
\hline RB966928 & $87,93 \mathrm{aA}$ & $78,16 \mathrm{bB}$ \\
\hline RB855453 & $85,12 \mathrm{bA}$ & $74,35 \mathrm{cB}$ \\
\hline $\begin{array}{l}\text { Averages on columns followed by the same letter do not differ ecstatically. It was used Scott-Knott test at 5\% } \\
\text { probability. Column: Capital letters; Rows: Small letters. }\end{array}$ \\
\hline
\end{tabular}

Souza et al. (2005) reported that values toward purity of broth must be over than $80 \%$ in the beginning of crop and $85 \%$ in its middle, most valued varieties are those ones which display greater values than $85 \%$. Only variety CTC9001 showed values lower than the recommended, 83,65\% of purity, as varieties RB975952 and RB966928 showed the highest values, 88,48 and $87,93 \%$. In 2017 , the second cultivation cycle, all the varieties were lower than recommended $(80-85 \%)$, however, among the studied varieties, only RB975952 ecstatically differed and showed a suitable purity value, $82 \%$. 
This interaction between the cultivation cycle shows that even it occurs a suitable management, the reduction of technological parameters could has happened due to the decrease in force of new plants of regrowth in the following year. Other factors may influence on these parameters as soil fertility (Zambrosi et al., 2017), biotic and abiotic stress, which favors a higher attack of plagues; harvest method (Showler, 2016) and even the adaptation to production ambience of the chosen variety.

However, it was not observed an interaction between the factor in the parameter total-recoverable sugar per ton of sugarcane (TRS), as Chart 4 displays.

Chart 4:- Average values of total-recoverable sugar per ton of sugarcane (TRS), percents of attacked stems (\%AS) and tons of sugarcane's stem per hectare (TSH) of sugarcane varieties of sugarcane attacked by borer.

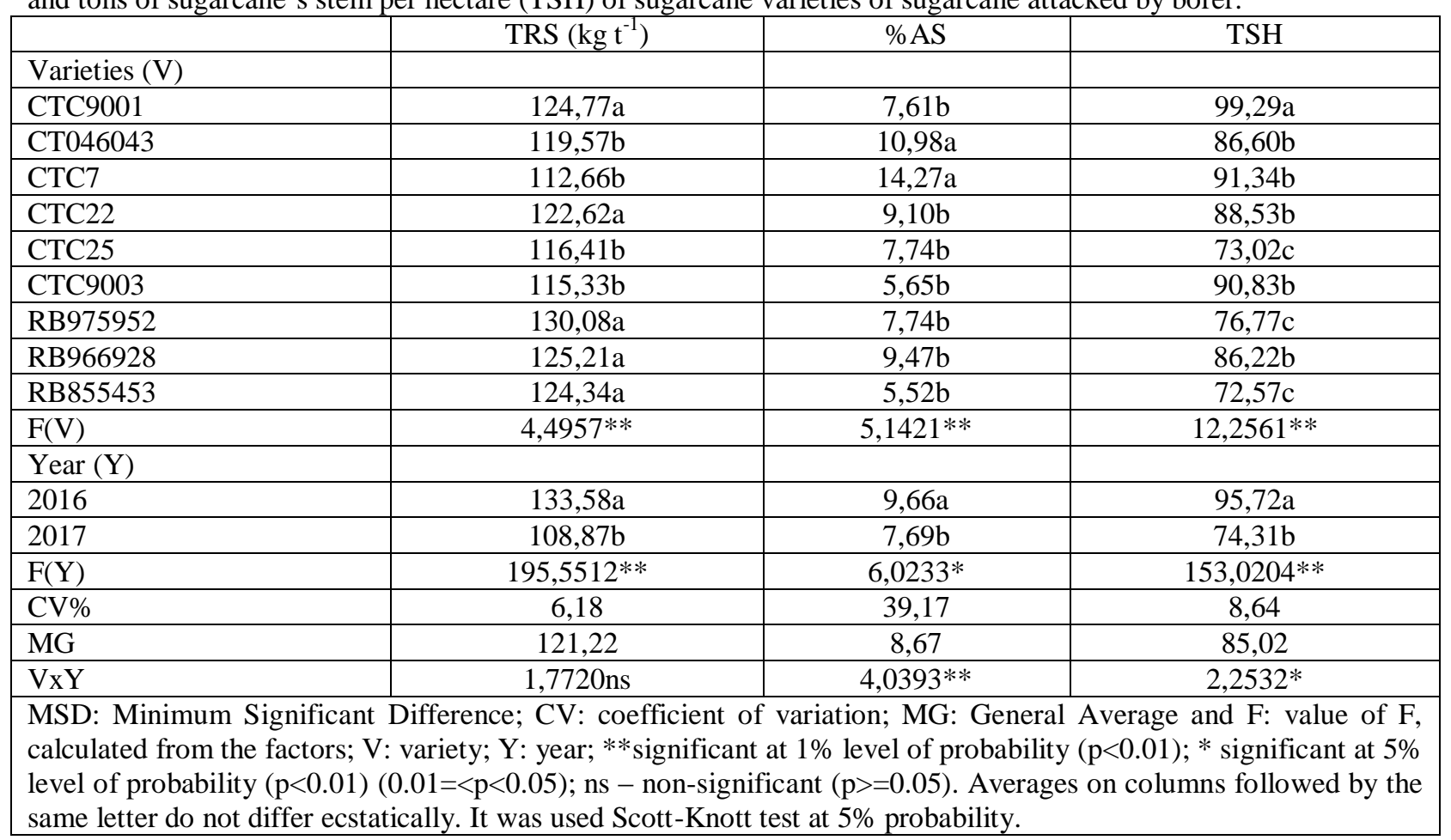

The first cultivation cycle showed a higher average value of TRS with $133,58 \mathrm{~kg} \mathrm{t}^{-1}$ of sugarcane, resulting in a 18,49\% difference towards the second cultivation cycle. Varieties CT046043; CTC7; CTC25 and CTC9003 showed lower TRS values, this decrease coincides with varieties that displayed a greater incidence of sugarcane borer, as Chart 5 shows.

\begin{tabular}{|l|c|c|}
\hline & 2016 & 2017 \\
\hline CTC9001 & $7,93 \mathrm{bA}$ & $7,29 \mathrm{bA}$ \\
\hline CT046043 & $14,47 \mathrm{aA}$ & $12,31 \mathrm{aA}$ \\
\hline CTC7 & $17,27 \mathrm{aA}$ & $11,27 \mathrm{aB}$ \\
\hline CTC22 & $11,53 \mathrm{aA}$ & $6,68 \mathrm{bA}$ \\
\hline CTC25 & $11,96 \mathrm{aA}$ & $3,51 \mathrm{bB}$ \\
\hline CTC9003 & $5,21 \mathrm{bA}$ & $7,50 \mathrm{bB}$ \\
\hline RB975952 & $7,88 \mathrm{bA}$ & $7,61 \mathrm{bA}$ \\
\hline RB966928 & $6,62 \mathrm{bB}$ & $6,09 \mathrm{bA}$ \\
\hline RB855453 & $4,07 \mathrm{bA}$ & $6,97 \mathrm{bA}$ \\
\hline $\begin{array}{l}\text { Averages on columns followed by the same letter do not differ ecstatically. It was used Scott-Knott test at 5\% } \\
\text { probability. Column: Capital letters; Rows: Small letters. }\end{array}$ \\
\hline
\end{tabular}


It was observed an interaction between the factors, in which CT046043; CTC7; CTC22 and CTC25 displayed greater values of attacked stems on the first cultivation cycle, however, on the second one, only varieties CT046043 and CTC7 showed a higher plague's influence as Chart 5 shows. This percentual variation reach 71,87\% of attacked stems on the first cultivation cycle. This difference between the varieties with lower and higher borer attack index reach $71,48 \%$ on the second cultivation cycle.

Varieties CT046043 and CTC7 also showed lower values of fiber (Chart 2), which proves that borer's attack can be decreased by using genetic modified varieties. That way, the 10-percent variation on the fiber content in sugarcane varieties can be favored plague's incidence nearly $71 \%$ in varieties with lower fiber content. This characteristic is an important factor in the selection of plants to genetical enhancement programs. (Showler, 2016; Ekpélikpézé et al., 2016; Tyagi and Naidu, 2016).

Due to borer's attack, an amount and quality reduction occurred in total-recoverable sugar (TRS), as observed in CT046043 and CTC7, which are among the varieties with the lowest TRS value (Chart 4). By decreasing sugar, sugarcane stems become lighter, consequently, a reduction in tons of sugarcane's stem per hectare (TSH) occurs.

A significant interaction was observed between the studied cultivation cycles, as Chart 4 shows. Chart 6 displays Average values of percentual unfolding of sugarcane's stem per hectare (TSH) attacked by borer.

Chart 6:- Average values of percentual unfolding of sugarcane's stem per hectare (TSH) attacked by borer.

\begin{tabular}{|l|c|c|}
\hline & 2016 & 2017 \\
\hline CTC9001 & $117,14 \mathrm{aA}$ & $81,44 \mathrm{aB}$ \\
\hline CT046043 & $95,30 \mathrm{bA}$ & $77,90 \mathrm{aB}$ \\
\hline CTC7 & $100,09 \mathrm{bA}$ & $82,60 \mathrm{aB}$ \\
\hline CTC22 & $98,53 \mathrm{bA}$ & $78,52 \mathrm{aB}$ \\
\hline CTC25 & $78,32 \mathrm{cA}$ & $67,72 \mathrm{bB}$ \\
\hline CTC9003 & $103,94 \mathrm{bA}$ & $77,73 \mathrm{aB}$ \\
\hline RB975952 & $85,61 \mathrm{cA}$ & $67,93 \mathrm{bB}$ \\
\hline RB966928 & $101,34 \mathrm{bA}$ & $71,09 \mathrm{bB}$ \\
\hline RB855453 & $81,24 \mathrm{cA}$ & $63,90 \mathrm{bB}$ \\
\hline Ave & . & \\
\hline
\end{tabular}

Averages on columns followed by the same letter do not differ ecstatically. It was used Scott-Knott test at $5 \%$ probability. Column: Capital letters; Rows: Small letters.

On the first cultivation cycle, only variety CTC9001 displayed higher average TSH values, with a 33,13\% difference as compared to CTC25, which showed the lowest average value. This result shows a positive response of variety CTC9001 to the production ambient. These results agree with Souza et al. (2006), as they studied sugarcane varieties on initial stages and verified that variety CTC9001 showed better response on dry mass production. While, on the second cultivation cycle, varieties CTC25; RB975952; RB966928 and RB855453 had a lower TSH production.

According to Silva et al. (2007), the fast and uniform initial growth of sugarcane allows infer in a good tillering stand, leading to a fast closing of the empty lines, consequently, to a effective control of invasive plants, as well as an increase on TSH. As described by Silva et al. (2017), a greater cover of leaves is an important factor on soil conservation and elevation in biomass production.

\section{Conclusion:-}

The varieties CT046043 and CTC7 had lower values of fiber and higher incidence of borer.

The presence of sugar cane drill reduced the quality and quantity of sugarcane stalks. The variation of $10 \%$ in fiber content in sugarcane caused a $71 \%$ difference in the incidence of Diatraea saccharalis.

\section{Acknowledgments:-}

Pedra Agroindustrial S / A - Ipê Plant Unit. 


\section{References:-}

1. Aude, MIS. (1993): Estágios de desenvolvimento da cana-de-açúcar e suas relações com a produtividade. Ciência Rural., 23 (2): 241-248. http://dx.doi.org/10.1590/S0103-84781993000200022

2. Banzatto, DA. and Kronka, SN. (2013): Experimentação Agrícola. 4.ed. Funep, 237p.

3. Consecana - Conselho dos Produtores de Cana-de-Açúcar, Açúcar e Etanol do Estado de São Paulo. (2006): Manual de instruções. 5. ed. Piracicaba:CONSECANA/publicações.

4. Costa, CTS., Ferreira, VM., Endres, L., Ferreira, DTRG. and Gonçalves, ER. (2011): Crescimento e produtividade de quatro variedades de cana-de-açúcar no quarto ciclo de cultivo. Revista Caatinga., 24: 56-63.

5. Daniel, JLP., Jacovaci, FA., Junges, D., Santos, MC., Lima, J.R., Anjos, IA., Landell, MGA., Huhtanen, P. and Nussio, LG. (2016): Fibre digestibility and its relationships with chemical and morphological traits in thirty-two sugarcane varieties. Grass and Forage Science., 72: 545-555. http://dx.doi.org/10.1111/gfs.12254

6. Dinardo-Miranda, LL. (2008): Pragas. In: Dinardomiranda, LL., Vasconcelos, ACM., Landell, M.G.A. (Ed.). Canade-açúcar. Campinas: Instituto Agronômico., pp.349-404.

7. Ekpélikpézé, OS., Dansi, A., Agbangla, C., Akoegninou, A. and Sanni, A. (2016): Biochemical Characterization of Sugarcane Varieties Cultivated in Benin. International Journal of Current Microbiology and Applied Sciences. 5 (2): 368-379. http://dx.doi.org/10.20546/ijcmas.2016.502.042

8. Empresa Brasileira De Pesquisa Agropecuária - Embrapa. (2013): Sistema brasileiro de classificação de solos. 3.ed. Brasília., 353p.

9. Lima, GSA., Cruz, MM., Lima, JS. and Tenorio, DA. Síndrome do amarelecimento foliar da cana-de-açúcar no estado de Alagoas. Ciência Agrícola., 9: 29-33.

10. Medeiros, AH., Mingossi, FB., Dias, RO., Franco, FP., Vicentini, R., Mello, MO., Moura, DS. and Silva-Filho, MC. (2016): Sugarcane serine peptidase inhibitors, serine peptidases, and clp protease system subunits associated with sugarcane borer (Diatraea saccharalis) herbivory and wounding. International Journal of Molecular Sciences., 17: 216. http://dx.doi.org/10.3390/ijms17091444

11. Raij, B., Cantarella, H., Quaggio, JA. and Furlani, AMC. (1996): Recomendações de adubação e calagem para o Estado de São Paulo. 2.ed. Campinas: IAC., 285p.

12. Ripoli, TCC., Ripoli, MLC. and Casagrandi, DV. (2006): Produção de cana-de-açúcar: estado da arte. Piracicaba: Ed. dos autores., 2016p.

13. Rodolfo Junior, F., Ribeiro Junior, WQ., Ramos, MLG., Rocha, OC., Batista, LMT. and Silva, FAM. (2016): Produtividade e qualidade de variedades de cana-de-açúcar de terceira soca sob regime hídrico variável. Nativa., 4 (1): 36-43. http://dx.doi.org/10.14583/2318-7670.v04n01a08

14. Showler, AT. (2016): Selected abiotic and biotic environmental stress factors affecting two economically important sugarcane stalk boring pests in the United States. Agronomy., 6 (1): 1-10. http://dx.doi.org/10.3390/agronomy6010010

15. Silva, FAS. and Azevedo, CAV. (2016): The Assistat Software Version 7.7 and its use in the analysis of experimental data. African Journal Agriculture Resarch., $11 \quad$ (39): 3733-3740. http://dx.doi.org/10.5897/AJAR2016.11522

16. Silva, MA., Gava, GJC., Caputo, MM., Pincelli, RP., Jeronimo, EM. and Cruz, JCS. (2007): Uso de reguladores de crescimento como potencializadores do perfilhamento e da produtividade em cana soca. Bragantia., 66 (4): 545-552. http://dx.doi.org/10.1590/S0006-87052007000400003

17. Silva, VSG., Oliveira, MW., Oliveira, TBA., Mantovanelli, BC., Silva, AC., Soares, ANR. and Clemente, PRA. (2017): Leaf area of sugarcane varieties and their correlation with biomass productivity in three cycles. African Journal of Agricultural Research., 12: 459-466. http://dx.doi.org/10.5897/AJAR2016.11817

18. Singh, P., Singh, M. and Sharma, B. (2016): Variation in sugar content between early and mid-late maturing sugarcane varieties across the crushing period in sub-tropical India. Proceedings of the International Society of Sugar Cane Technologists., 29: 1919-1922.

19. Souza, FJM., Pascoaloto, IM., Figueiredo, PAM., Lima, CR. and Lisboa, LAM. (2016): Parâmetros biométricos do crescimento e desenvolvimento da cana-de-açúcar (Saccharum spp.) nas suas fases iniciais. Revista Mirante., 9 (1): 159-168.

20. Souza, ZM., Paixão, ACS., Prado, RM., Cesarin, LG. and Souza, SR. (2005): Manejo de palhada de cana colhida sem queima, produtividade do canavial e qualidade do caldo. Ciência Rural., 35 (5): 1062-1068. http://dx.doi.org/10.1590/S0103-84782005000500012

21. Tyagi, AP. And Naidu, P. (2016): Sugarcane (Saccharum officinarum) variety evaluation for quantitative charac-ters (Pure obtainable cane sugar, sucrose content and cane yield). Journal of South Pacific Agriculture., 19 (1): 43-55. Zambrosi, FCB., Ribeiros, RV., Machado, EC. and Garcia, JC. (2017): Phosphorus deficiency impairs shoot regrowth of sugarcane varieties. Experimental Agriculture., 53 (1): 1-11. http://dx.doi.org/10.1017/S0014479715000290 